\title{
Economic and Mathematical Modelling for Evaluation of Potential Recreational Forest Utilization
}

\author{
Yevstakhii Kryzhanivskyi \\ Rector \\ Ivano-Frankivsk National Technical \\ University of Oil and Gas \\ Ivano-Frankivsk, Ukraine \\ rector@nung.edu.ua \\ Oleksii Holubchak \\ P. S. Pasternak Research Institute for \\ Mountain Forestry \\ Ivano-Frankivsk, Ukraine \\ girlis@ukr.net
}

\author{
Liliana Horal \\ Department of Finance \\ Ivano-Frankivsk National Technical \\ University of Oil and Gas \\ Ivano-Frankivsk, Ukraine \\ https://orcid.org/0000-0001-6066-5619 \\ Mykytiuk Nataliia \\ Department of management \\ Ivano-Frankivsk National Technical \\ University of Oil and Gas \\ Ivano-Frankivsk, Ukraine \\ nataliamykytiukmmm@gmail.com
}

\author{
Vira Shyiko* \\ Department of Finance \\ Ivano-Frankivsk National Technical \\ University of Oil and Gas \\ Ivano-Frankivsk, Ukraine \\ https://orcid.org/0000-0002-2822-0641
}

\begin{abstract}
The need to identify the potential of recreational forest management as one of the priority development courses of the tourist and recreational industry. Based on studies of domestic and foreign scientists, it was established that the potential of recreational forest management is a four-component phenomenon and includes a resource-based, economic, social and innovation and investment components. Considering this aspect, a method of economic evaluation of the potential of recreational forest management was proposed, based on taxonomic analysis methods for economic and mathematical modelling of integral indicator of the potential level of recreational forest management. This method was tested by the example of the recreation area of the Western Ukrainian region. It was determined that the integral indicator of the level of potential of forest management potential at the investigated sites is low. Its main reserves are to improve its economic, innovation and investment component, but it is necessary to maintain a high level of resource and social component. Measures and ways to increase the level of recreational forestry potential are proposed.
\end{abstract}

Keywords - recreation, forest management, economic evaluation, potential.

\section{INTRODUCTION}

As foreign experience $[1,2,3,4,5]$ shows, recreation is an important and large-scale strategic branch of economic activity, becoming more investment-attractive year by year and, along with a measure of cultural development of the country, can serve as a sufficiently high source of the state budget revenue and local budgets. Recreational activities have important sense in the economies of countries and regions, ensuring rational use and conservation of natural, ecological, cultural, historical, information and cognitive resources of the territory [6]. Unfortunately, there is no effective use of existing recreational potential of the regions in Ukraine, thus, leading to the loss of opportunities for development of this industry unlike many countries in the world. Therefore, there is a need to evaluate the available recreational resources and existing recreational potential of the country as a whole and its individual administrative territories and develop directions and ways to increase their efficiency.

\section{BACKGROUND}

Scientists and experts from different countries, dealing with forest management issues, are increasingly expressing the view that recreational forest management prevails over industrial forest use. At the same time, the prospects for development of recreational forest management have been proven by scientists by justification of a growing set of useful functions of recreational forest management.

An important aspect and meaningful reason in the fight for the priority of recreational forest management against its so-called "special use" under the Forestry Code, may be an adequate economic evaluation of the potential of recreational forest management. However, this issue requires further study both by domestic and foreign scientists and experts. Therefore, this article will provide critical analysis of evaluation methods of recreational potential of forest management with justification of adaptive moments of developed methods and formation of a complete set of methods used to evaluate potential of recreational forest management in terms of economic justification for development of this tourist and recreational sphere.

Among foreign scientists, who studied the problem of recreational forest management Bell Simon [1], William Murphy [2], and Lloyd C. Irland, Darius Adams, Ralph Alig, Carter J. Betz, Chi-Chung Chen,Mark Hutchins, Bruce A. McCarl, Ken Skog, Brent L. Sohngen [3], Nerida Anderson, Rebecca M Ford, Lauren T Bennett, Craig Nitschke,Kathryn J H Williams [4], Artti Juutinen, AnnaKaisa Kosenius and Ville Ovaskainen [5] may be mentioned in this regard.

Bell Simon proved in his work, that forest recreation is likely to gain in importance throughout Europe. The 
declining values of timber and increasing focus on environmental quality and pursuit of better health and wellbeing have transformed the agenda. Foresters have a huge opportunity to capitalise on these trends and to offer something that is highly effective yet relatively cheap in terms of improving the health and well-being of the population. It is time that foresters demonstrated this value for money and obtained even a fraction of the resources available to health services - this would make a huge difference [1]. William Murphy in his work [2] proves, that recreation is an increasingly important function of the forest, delivering a broad range of benefits to society and supporting rural tourism and economic development. Forest owners, both large and small, are critical to delivering these functions. However, frequently they see little in terms of economic dividend from this provision. Coillte contends that such services, whether provided by large or small landowners, shall be supported by fund transfers. The mechanisms exist to calculate these nonmarket benefits. Coillte commissioned a study in 2005 to evaluate the contribution their forests make to national well-being and also the economic activity recreation generates in rural communities. The study used both Willingness To Pay and Costless Choice methods to evaluate the nonmarket benefits (€97 million) and economic activity (€268 million). Recreation can also be delivered when commercial focus and market demand are aligned. Two examples of bringing a market focus to delivering forest recreation are outlined in paper [2].

Lloyd C. Irland, Darius Adams, Ralph Alig, Betz, ChiChung Chen, Carter J, Mark Hutchins, Bruce A. McCarl, Ken Skog, Brent L. Sohngen in their scientific studies [3] prove the relevance of development of recreational forest management in terms of evaluating socioeconomic effects of climate switch on US woods, forest-product markets, and forest recreation and they show that two new statistical research attempted to describe the climate responsiveness of recreation vacation on a national basis. Roughly calculated effects of climate switch on picked outdoor recreation bustle in the US. They estimated contemporary aggregate days of activity and the economic value to visitors, and they projected these variables to 2060. The consequence suggest losses in user benefit for some activities and obtain for others. in spite of everything, the analysis of the recreation impacts of climate switch is in its infancy. Understandably many forms of converting can accompany climate vary, though they may foist higher costs. The consequence of recreation as a characteristic in the quality of life, its economic impact, its clear climate sensitivities, and the many local and regional variations contend for a major increase in researches on this topic [3]. Nerida Anderson, Rebecca M Ford, Lauren $\mathrm{T}$ Bennett, Craig Nitschke, Kathryn J H Williams in their work [4] study the problem of balancing the values of forests for people. This paper addresses one source of ambiguity by examining forest values at two levels of abstraction: core values of people (principles that guide in life), and valued attributes of forests (qualities of forests important to people). They used in-depth interviews with 36 members of the public in Victoria, Australia to describe the values relevant to forests at both levels. Then they examined relationships between values based on a survey of members of the Victorian public. Their study revealed valued attributes encompassing natural, production, cultural and experiential categories. In the paper authors demonstrated a broader range of core values relevant to forest management than previously recognized: security (safety and stability of society) and hedonism (pleasure and sensory gratification) were expressed in addition to biospheric, altruistic and egoistic values. Associations between core values and valued attributes revealed biospheric values underpin variation in the importance given to production and natural attributes of forests. The core value of security also underpinned multiple valued attributes. By revealing a comprehensive yet succinct range of values associated with forests, this research supports development of forest policy congruent with expectations of society [4]. Artti Juutinen, Anna-Kaisa Kosenius and Ville Ovaskainen in their scientific studies "Estimating the benefits of recreation-oriented management in state-owned commercial forests in Finland" shows that the choice experiment counts Finnish people's estimate of the recreation-oriented management of state-owned commercial woods to assess whether the recreational advantage produced justify the connected loss of profits from timber sales. They focus on three allocate: scenic buffer area, along lakes and rivers, habitats for game, and the quality of scenery as reflected by the frequency of clear-cut areas along hiking trails. Insignificant willingness-to-pay (WTP) effects for the ascribes are estimated with unsystematic parameters logit models identifyed in the WTP space, while preference-space models are used to roughly calculate in physical terms the ascribes levels that maximize the advantages, to the public. In spite of regional differences in favourites, people in Finland valued the valid recreation-oriented management of state-owned commercial woods significantly. National, the aggregate advantages of recreation-enhancing administration clearly prevailed the estimated opportunity losses. The most favoured levels of administration were lightly above the valid levels, suggesting an growth in the implementation of recreational kindness when not considering the associated expense [5]. Among national scientists, studying problems of recreational forest management the following scientists can be mentioned: I. F. Kalutskyi [6], M. M. Kutia and V. A. Svynchuk [7], A. Yatsenko [8], I. H. Kotsiuba [9]. Tokareva O. V. [10] et al. Summarizing scientific achievements of domestic scientists, studying the problem to evaluate the potential of recreational forest management, we can conclude that in Ukraine the issue of economic evaluation of the potential of recreational forest management has not been properly investigated. Domestic scientists are mainly focused on determining reserves [6] and prospects for development of recreational forest management [8], optimization of recreational forest management $[7\rceil$ based on analysis and evaluation of recreational and environmental characteristics of forests [9, 10]. Undoubtedly, these characteristics are essential to provide evaluation of the potential of recreational forest management, but the following economic characteristics shall also be considered: costs on recreational area improvement works, efficiency of recreational activities, the degree of deterioration of fixed assets of recreational areas, use of recreational activities for marketing, marketing recreational sites, mechanisms and schemes of financial and investment support for development of recreational facilities on forest areas. Therefore, considering sufficiently thorough scientific works of both foreign and domestic researchers of the recreational forest management problems and without diminishing their scientific value to improve development of recreational forest management, we can conclude that 
economic evaluation of the recreational forest management potential is still to be studied. Therefore, we consider it necessary to form a methodology to evaluate the potential of recreational forest management.

\section{MeTHODOLOGY}

As it is known, for complex evaluation of every economic process or its components methods of integral indicators calculation are conventionally applied using different economic and mathematical methods and approaches. The complex evaluation is required to define potential of recreational forest management, considering development of all its components. Therefore, we propose to evaluate the potential of recreational forest use by performing the following steps: to identify recreational forest management potential components; develop and form a system of quantitative and qualitative indicators (indices) to evaluate the efficiency of recreational forest management potential by its component composition; to evaluate efficiency of recreational forest management of the regional territories by individual components of the recreational forest management potential using certain indicators; comprehensively evaluate efficiency of each recreational forest management potential component; conduct an integral evaluation of efficiency of recreational forest management using taxonomic analysis methods and fuzzy set theory; to determine the level of the recreational forest management potential use by comparing the integral indicator value with its standard (critical) values.

Based on experience of previous studies of recreational forest management, the following structural components of recreational forest management potential can be formed: a resource component, social component, economic component, innovation and investment component. Each component of recreational forest management is characterized by a system of performance indicators. According to the above characteristics of each component, the following system of indicators can be proposed, considering attributes of recreational activity, they are listed in Table 1 .

Therefore, the next stage of economic and mathematical modelling of evaluation of the recreational forest management potential is to determine efficiency of recreational forest management of regional territories by individual components of recreational forest management potential using indicators specified in Table 1. For this stage, we use a taxonomic method based on determination of taxonomic indicators of each component. The determination of taxonomic indicators begins with identification of elements of observation matrix $X$, its elements are represented by indicator values expressed in units, specific for each indicator. The standardization shall be performed. The procedure for standardization of indicators leads to elimination of measurement units and alignment of indicator values.

Using element multiplicity w described by n-signs, each unit can be interpreted as a point of n-dimensional space with coordinates equal to the value of $n$ attributes for the analysed unit. Let us represent the matrix as follows:

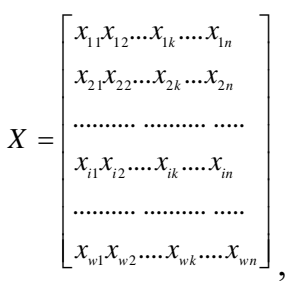

where: $w$ is the number of study periods, $\mathrm{n}$ is the number of indicators of each recreational forest management potential, $x_{i k}$-indicator value $\mathrm{k}$ of each specific component for a year $(k=1 \div n, i=1 \div w)$.

The differentiation of the observation matrix attributes is based on the study of each attribute impact on the level of recreational forest management potential, as well as the distribution of attributes by the positive (as a set of stimulants) and negative impact (a set of stimulants) on the recreational forest management potential. A high level of a certain attribute will determine a positive character, a low level will determine a negative character of the comparison attribute. This differentiation will make it possible to choose reference points in the variation of sustainability level indicators of land regulation.

The attributes are standardized according to the formula:

$$
z_{i k}=\frac{x_{i k}-x_{k}}{s_{k}},
$$

when

$$
\begin{gathered}
\bar{x}_{k}=\frac{1}{w} \sum_{i=1}^{w} x_{i k}, \\
S_{k}=\left[\frac{1}{w} \sum_{i=1}^{w}\left(x_{i k}-\bar{x}_{k}\right)^{2}\right]^{\frac{1}{2}},
\end{gathered}
$$

where: $z_{i k}-$ standardized value of indicator $\mathrm{k}$ for the $\mathrm{i}$-th study period; $x_{i k}-$ standardized value of indicator $k$ for the $i$ th study period; $x_{k}-$ arithmetic mean of $k$ indicator; $S_{k}-$ standard deviation of $\mathrm{k}$ indicator; $w$-a number of periods.

As a result of observation matrix standardization, we obtain the following matrix:

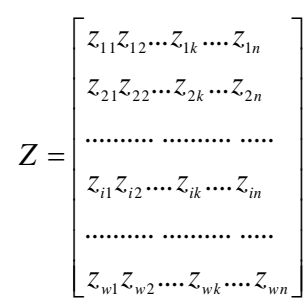

However, after standardization, some attributes may lose their meaning because these attributes are considered to be equivalent and this approach distorts real values. 
TABLE I. EVALUATION INDICATORS OF THE RECREATIONAL FOREST MANAGEMENT POTENTIAL COMPONENTS

\begin{tabular}{|c|c|c|}
\hline Component & Indicator & Substantiation \\
\hline \multirow{5}{*}{$\begin{array}{l}\text { Resource } \\
\text { component }\end{array}$} & Area of recreational territories, $\mathrm{km} 2$ & Total area of forestry intended for recreational forest management \\
\hline & Number of recreational sites, quantity & $\begin{array}{l}\text { Number of recreational sites located on the forestry territory intended for recreational } \\
\text { forest management }\end{array}$ \\
\hline & $\begin{array}{l}\text { The level of attractiveness of natural and } \\
\text { recreational resources }\end{array}$ & $\begin{array}{l}\text { The indicator can be evaluated according to the following criteria: exoticism, uniqueness, } \\
\text { aesthetics, comfort, etc. }\end{array}$ \\
\hline & Quality factor of forest vegetation & It describes their level of recreation applicability [11] \\
\hline & $\begin{array}{l}\text { Exoticism degree (contrast) of recreational } \\
\text { territory }\end{array}$ & $\begin{array}{l}\text { It is determined as a contrast ratio degree of the resting place relative to a recreant's } \\
\text { permanent residence }\end{array}$ \\
\hline \multirow{5}{*}{$\begin{array}{l}\text { Economic } \\
\text { component }\end{array}$} & $\begin{array}{l}\text { A share of total forestry costs on } \\
\text { maintenance of recreational sites, } \%\end{array}$ & It shows the share of the total costs on maintenance of recreational territories \\
\hline & $\begin{array}{l}\text { Efficiency factor of recreational forest } \\
\text { management }\end{array}$ & It shows attractiveness of recreational forest management [11] \\
\hline & $\begin{array}{l}\text { Wear coefficient of recreational fixed } \\
\text { assets (FA) }\end{array}$ & It characterizes wear level of recreational fixed assets \\
\hline & $\begin{array}{l}\text { Volume of marginal costs for growing } 1 \\
\text { ha of recreational forest }\end{array}$ & $\begin{array}{l}\text { They reflect the effect, achieved by improving the forest as a means of labor in recreation } \\
\text { sphere [11] }\end{array}$ \\
\hline & Capacity of a single recreational load & It shows the maximum permissible number of persons on recreational territory \\
\hline \multirow{4}{*}{$\begin{array}{l}\text { Social } \\
\text { component }\end{array}$} & A share of recreant employees & $\begin{array}{l}\text { It shows a share of recreant employees in the total number of staff involved in recreational } \\
\text { activities }\end{array}$ \\
\hline & Recreational capacity & $\begin{array}{l}\text { The capacity of recreation centres (resorts, tourist, health, recreational complexes) is a } \\
\text { simultaneous number of recreants that can be located in this centre, without disturbing } \\
\text { ecological balance within this centre and surrounding territories [12]. }\end{array}$ \\
\hline & Recreational load per 1 ha of forest & It determines attendance intensity for any segment of the day, during weekends, weekdays \\
\hline & $\begin{array}{l}\text { The average stay of vacationers on the } \\
\text { recreational territory, } \mathrm{h} \text {. }\end{array}$ & It shows an average length of stay of visitors on the recreational territory of forest area \\
\hline \multirow{5}{*}{$\begin{array}{l}\text { Innovation } \\
\text { and } \\
\text { investment } \\
\text { component }\end{array}$} & $\begin{array}{l}\text { Cost amount on marketing activities of } \\
\text { recreational territories }\end{array}$ & It characterizes the development level of marketing activities \\
\hline & $\begin{array}{l}\text { Efficiency of innovation implementation } \\
\text { of recreational forest management }\end{array}$ & It characterizes the innovation level and efficiency of recreational innovation use \\
\hline & $\begin{array}{l}\text { Amount of investments in recreational } \\
\text { activity }\end{array}$ & It shows the amount of investment resources aimed at recreational activities \\
\hline & $\begin{array}{l}\text { A share of foreign investments in } \\
\text { recreational activities financing }\end{array}$ & $\begin{array}{l}\text { It shows amount of recreational activity financing at the expense of foreign financial } \\
\text { sources }\end{array}$ \\
\hline & $\begin{array}{l}\text { Quantity of grants (programs) won to } \\
\text { finance recreational activities }\end{array}$ & It characterizes urgency of the recreational sphere development \\
\hline
\end{tabular}
depending on their significance $[13,14]$. These coefficients will reflect the role, value, and position of each attribute in the studies performed. The calculated values of hierarchy coefficients can be determined based on the critical distances of the largest distance $\rho$ between the nearest adjacent attributes.

$$
k=\max _{i} \min _{j} \rho\left(\alpha_{i}, \alpha_{j}\right)
$$

The proposed hierarchy coefficients are calculated in the following order:

all distances, not exceeding critical distances, for each attribute of the observation matrix are calculated by the formula: the distances, obtained for each element are calculated by the formula:

$$
w_{i}=\sum_{(i, j)=Q} \rho\left(\alpha_{i}, \alpha_{j}\right)
$$

then the attribute is selected, for which the calculated sum of distances is the highest one:

$$
w_{m}=\max _{i} w_{i}
$$

the hierarchy coefficient is calculated: 


$$
\gamma=\frac{w_{i}}{w_{m}}
$$

By multiplying values of each standardized attributes by the hierarchy coefficient, corrected values of the corresponding attribute are used for taxonomic analysis.

The next step is the problem analysis of observation matrix differentiation. All variables are divided into stimulants and disincentives. The indicators of each component are divided into two groups based on the impact character of each of them on recreational forest management potential. Indicators, having a positive effect on recreational forest management potential, are considered stimulants, in contrast to the negative indicators, having a negative effect the stimulants and, thus, reducing the level of recreational forest management potential.

Distribution of indicators into stimulants and disincentives serves as the basis to develop the so-called standard, represented by point $\mathrm{P}_{\mathrm{o}}$ with coordinates: $z_{01}, z_{02}, \ldots$ $z_{0 n}$

$$
\begin{aligned}
& z_{0 s}=\max z_{r s}, \text { if } s \in I \\
& z_{0 s}=\min z_{r s}, \text { if } s \notin I(s=1,2 \ldots n)
\end{aligned}
$$

where: $I$ is a set of stimulants, $z_{r s}$ is a standardized value of the exponent $\mathrm{s}$ of a specific block of costs for period $\mathrm{r}$.

The distance between individual unit points and point Po, representing the standard of cost level, is expressed as $c_{i o}$ and calculate as follows:

$$
C_{i 0}=\left[\sum_{s=1}^{n}\left(z_{i s}-z_{0 s}\right)^{2}\right]^{\frac{1}{2}} \quad(i=1, \ldots . ., w)
$$

The obtained distances are considered as initial values used to calculate the indicator of recreational forest management potential:

$$
\begin{gathered}
d_{i}=1-\frac{c_{i 0}}{c_{0}} \\
c_{0}=\frac{1}{w} \sum_{i=1}^{w} c_{i 0}, \\
S_{0}=\left[\frac{1}{w} \sum_{i=1}^{w}\left(c_{i 0}-c_{0}\right)^{2}\right]^{\frac{1}{2}},
\end{gathered}
$$

This indicator is interpreted as follows: it assumes a high value at high stimulus values and a low value at low stimulus values. The closer the figure is to one, the higher the level of recreational forest management potential. The indicator of recreational forest management potential can serve for statistical characterises of elements infinity. It is possible to estimate the "average" level of the indicators, achieved within a certain period of time characterizing the analysed problem.

\section{RESULTS AND DISCUSSION}

To approve the methodology for assessing the recreational potential of forest use, a typical forestry of the Western region of Ukraine was selected, including 8 forestries. It is worth mentioning that as a result of the underdeveloped information and statistical infrastructure of forestries, it was not possible to calculate a required system of indicators, shown in Table 1. However, based on actual

\begin{tabular}{|c|c|c|c|c|c|c|c|c|}
\hline Indicator & 预 & 苞 & $\sum_{0}^{\infty}$ & 葡 & $\sum_{0}^{n}$ & 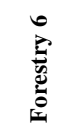 & 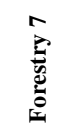 & 竞 \\
\hline $\begin{array}{l}\text { Taxonomic } \\
\text { indicator of } \\
\text { resource } \\
\text { component }\end{array}$ & 1.00 & 0.51 & 0.33 & 0.36 & 0.32 & 0.33 & 0.31 & 0.33 \\
\hline $\begin{array}{l}\text { Taxonomic } \\
\text { indicator of } \\
\text { social } \\
\text { component }\end{array}$ & 1.00 & 0.56 & 0.56 & 0.30 & 0.30 & 0.21 & 0.39 & 0.39 \\
\hline $\begin{array}{l}\text { Taxonomic } \\
\text { indicator of } \\
\text { economic } \\
\text { component }\end{array}$ & 0.00 & 0.00 & 0.00 & 0.00 & 0.00 & 0.00 & 0.00 & 0.00 \\
\hline $\begin{array}{l}\text { Taxonomic } \\
\text { indicator of } \\
\text { innovation } \\
\text { and } \\
\text { investment } \\
\text { component }\end{array}$ & 0.00 & 0.00 & 0.00 & 0.00 & 0.00 & 0.00 & 0.00 & 0.00 \\
\hline $\begin{array}{l}\text { Integral } \\
\text { indicator of } \\
\text { recreational } \\
\text { forest } \\
\text { management } \\
\text { potential } \\
\text { level }\end{array}$ & 0.50 & 0.27 & 0.22 & 0.16 & 0.16 & 0.14 & 0.17 & 0.18 \\
\hline
\end{tabular}
statistical base on the resource and social components each forestry, taxonomic indicators were calculated. The calculation results according to formulas $1-15$ on the results of forestry activity are summarized in Table 2 .

TABLE II. TAXONOMIC ANALYSIS RESULTS OF RECREATIONAL FOREST MANAGEMENT OF A TYPICAL FORESTRY

Therefore, based on obtained calculations we can conclude that recreational forest management in Ukraine is low, confirmed by the level of recreational forest management potential (Table 2). Of 8 analysed forests only in Forestry 1 the potential level is average, in two forestries the integral indicator of recreational forest management potential level has been set at a level below average, and the remaining 5 forests have a low level of recreational forest management. Graphically obtained results are shown in Figure 1

\section{CONCLUSION}

Thus, according to the results of economic and mathematical modelling of the integral indicator of recreational forest management potential level, it can be concluded that the recreational forest management potential in Ukraine is low (Figure 1), so measures shall be taken to improve recreational activity results and develop this industry. As the calculations indicate, first of all, it is urgent 
to develop economic and innovation investment components of the recreational forest management potential in Ukraine. Table 3 summarizes ways and directions to enhance recreational forest management potential.

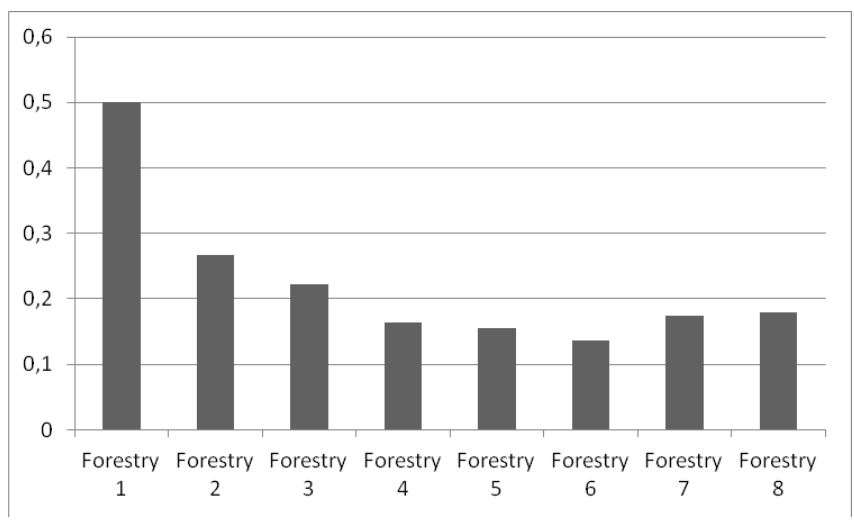

Fig. 1. Integral indicator of recreational forest management level

TABLE III. WAYS AND DIRECTIONS TO ENHANCE RECREATIONAL FOREST MANAGEMENT POTENTIAL ACCORDING TO ITS IDENTIFIED COMPONENTS

\begin{tabular}{|c|c|}
\hline $\begin{array}{l}\text { Recreational } \\
\text { forest } \\
\text { management } \\
\text { potential } \\
\text { component }\end{array}$ & $\begin{array}{l}\text { Ways and directions to enhance recreational } \\
\text { forest management potential }\end{array}$ \\
\hline $\begin{array}{l}\text { Resource } \\
\text { component }\end{array}$ & $\begin{array}{l}\text { Extension of recreational forest areas according to } \\
\text { demand analysis for this type of recreation; } \\
\text { Expansion in the number of recreational sites; } \\
\text { Rise of attractiveness level of recreational areas, } \\
\text { based on criteria of uniqueness, aesthetics, comfort, } \\
\text { pedestrian accessibility, exoticism, etc.; } \\
\text { Improvement of forest vegetation quality. }\end{array}$ \\
\hline $\begin{array}{l}\text { Economic } \\
\text { component }\end{array}$ & $\begin{array}{l}\text { Increase of costs on the maintenance of recreational } \\
\text { territories and marginal costs to increase the } \\
\text { recreational attractiveness of the territories; } \\
\text { Increase of capacity according to standards of } \\
\text { recreational load of the territories. }\end{array}$ \\
\hline $\begin{array}{l}\text { Social } \\
\text { component }\end{array}$ & $\begin{array}{l}\text { Increase of share of recreant employees in the staff } \\
\text { of forestries; } \\
\text { Increase of recreational capacity up to the level } \\
\text { compliant with ecological balance; } \\
\text { Recreational load optimization. }\end{array}$ \\
\hline $\begin{array}{l}\text { Innovation and } \\
\text { investment } \\
\text { component }\end{array}$ & $\begin{array}{l}\text { Development of a marketing support system for } \\
\text { recreational sites; } \\
\text { Development of an optimal financing scheme for } \\
\text { financing recreational areas with involvement of } \\
\text { external and internal sources of financing, as well as } \\
\text { programs for grant support and development of } \\
\text { recreational areas. }\end{array}$ \\
\hline
\end{tabular}

As a rule, owing to the fact there are large reserves to enhance the recreational forest management potential in Ukraine, it is important to consider the demand and level of ecological load of recreational areas. Thus, the next stage in the study of economic foundations of recreational activity is the economic and mathematical modelling of the process aimed at optimization of economic efficiency of recreational forest management, considering criteria of recreational, environmental safety and the demand for recreational forest management services.

\section{REFERENCES}

[1] S. Bell, "Forest recreation: New opportunities and challenges for forest managers Rad", Forestry on Treshold of EU - Sixty years of work and development of forest institutes in Croatia Stubicke toplice, 24-25 November 2005.

[2] William Murphy "Forest Recreation in a Commercial Environment" Small Scale Foresty Conference Proceedings. National Council for Forest Research and Development, 2006.

[3] Lloyd C. Irland, Darius Adams, Ralph Alig, Carter J. Betz, ChiChung Chen,Mark Hutchins, Bruce A. McCarl, Ken Skog, Brent L. Sohngen View, "Assessing Socioeconomic Impacts of Climate Change on US Forests, Wood-Product Markets, and Forest Recreation: The effects of climate change on forests will trigger market adaptations in forest management and in wood-products industries and may well have significant effects on forest-based outdoor recreation", BioScience, vol. 51, Issue 9, September, pp. 753764, 2001.

[4] Nerida Anderson, Rebecca M Ford, Lauren T Bennett, Craig Nitschke and Kathryn J H Williams, "Core values underpin the attributes of forests that matter to people", Forestry: An International Journal of Forest Research, Vol. 91, Issue 5, December, pp. 629-640, 2018.

[5] Artti Juutinen, Anna-Kaisa Kosenius and Ville Ovaskainen (2014), "Estimating the benefits of recreation-oriented management in stateowned commercial forests in Finland: A choice experiment", Journal of Forest Economics, vol. 20, Issue. 4, pp 396-412, 2014.

[6] I. F.Kalutskiy, "RecreationalForest Use in the Precarpathian Region, the Reserves of its Development and Use", Karpatskyi kray, vol. 2, pp.50-59, 2012. [in Ukrainian].

[7] M. M. Kutia and V. A. Svynchuk, "Using the analytic hierarchy process optimization in practice recreational forest", Lisivnytstvo ta dekoratyvne sadivnytstvo, Vol. 198(2), pp. 38-44, 2014.

[8] A. D. Yatsenko, "To the definition of "Recreational Forestry", Geography and tourism, vol. 22, pp. 95-98, 2012. [in Ukrainian].

[9] I Kotsyuba, "Environmental assessment of recreational forest management on the territory of the nature reserve fund of zhytomyr region", Transactions of Kremenchuk Mykhailo Ostrohradskyi National University, vol. 2, pp. 184-188, 2014. [in Ukrainian].

[10] O. Tokareva "Features of climatic comfort of recreation conditions in different types of forest park landscapes", Lisivnytstvo ta dekoratyvne sadivnytstvo vol. 171(1), pp. 222-225, 2012. [in Ukrainian].

[11] N. V. Fomenko, Recreational resources and balneology, Kyiv, UA: Tsentr navchalnoi literatury, 2007. [in Ukrainian].

[12] V. S. Kravtsiv, L.S. Hryniv, M.V. Kopach and S.P. Kuzyk Scientific and methodological principles of recreational sphere reforming, Lviv: NAN UA: Naukove vydannia, 1999. [in Ukrainian].

[13] V.Ie. Bakhrushyn, Methods of data analysis: a textbook for students, Zaporizhzhia: KPU, 2011. [in Ukrainian].

[14] V. Pliuta Comparative multivariate analysis in economic research. Taxonomy and factor analysis methods, M.: Statystyka, 1980. [in Ukrainian]. 